\title{
Lack of Fruit Set Caused by Ovule Degeneration in Japanese Plum
}

\author{
María Engracia Guerra \\ Departamento de Hortofruticultura, Centro de Investigación Agraria 'Finca La Orden-Valdesequera,' \\ A-V, km 374, 06187 Guadajira, Badajoz, Spain \\ Ana Wünsch \\ Departamento de Fruticultura, Centro de Investigación y Tecnología Agroalimentaria de Aragón \\ (CITA), Av. Montañana 930, 50059 Zaragoza, Spain \\ Margarita López-Corrales \\ Departamento de Hortofruticultura, Centro de Investigación Agraria 'Finca La Orden-Valdesequera,' \\ A-V, km 374, 06187 Guadajira, Badajoz, Spain \\ Javier Rodrigo ${ }^{1}$ \\ Departamento de Fruticultura, Centro de Investigación y Tecnología Agroalimentaria de Aragón \\ (CITA), Av. Montañana 930, 50059 Zaragoza, Spain
}

\begin{abstract}
Additional Index words. Prunus salicina, female sterility, pollen germination, pollen-pistil incompatibility, pollen tube growth, pollination, $S$-RNase alleles

Aвstract. Some japanese plum (Prunus salicina) cultivars are particularly prone to erratic fruit set showing very low or even null fruit set for reasons that are not clear. To ascertain the causes of lack of fruit set in some of them, different factors intervening in the reproductive process have been evaluated using flowers of three cultivars, Angeleno, Rubirosa, and Sweet August, from commercial orchards with records of very low fruit set in previous seasons and compared with a producing cultivar, Simka. Different cultivars coincident at flowering with the cultivars studied were evaluated as adequate pollenizers in each orchard. To determine which factors that intervene in the reproductive process could be related to the lack of fruit set, microscopic observations of pollen germination, pollen tube growth, pollen-pistil incompatibility, and ovule development were analyzed in flowers of different pollination treatments. Results allowed dismissal of pollen viability, pollen transfer, and pollen-pistil incompatibility as the cause of lack fruit set. However, the observation of ovule development revealed a high incidence of premature ovule degeneration on final fruit set in the three low-producing cultivars. The lack of fruit set in orchards with no apparent adverse environmental conditions is traditionally studied by analyzing the pollination process and the pollen-pistil incompatibility relationships, but the stage of development of the ovules is not usually considered. The approach used in this work may prove valuable to other species and situations of lack of fruit set, which could help to identify the causes for premature ovule degeneration.
\end{abstract}

Japanese plum is widely cultivated in temperate zones since its introduction in California from Japan in the 19th century (Faust and Surányi, 1999). The term japanese plum originally was applied to Prunus salicina but currently does not correspond to a pure species but it comprises a heterogeneous group of diploid fresh-market plums that were derived from the interspecific hybridization of the original species with other diploid Prunus (Byrne, 1989; Faust and Surányi, 1999; Okie, 2006). World production of japanese plums has been increasing in the last decades (Hartmann and Neümuller, 2009; Okie and Hancock, 2008), and an important renewal of plant material is taking place with the introduction of new cultivars from

Received for publication 15 July 2011. Accepted for publication 7 Sept. 2011. Financial support for this research was provided by the Spanish Ministry of Science and Innovation-European Regional Development Fund (ERDF), European Union (project grants: AGL2009-12621-C02-02; INIA RTA2009-00144), Government of Aragon (Grupo de Excelencia A-43), and OPFH Frugalia SL. María Engracia Guerra was financed by an Instituto Nacional de Investigación y Tecnología Agraria y Alimentaria (INIA) doctoral fellowship.

We gratefully acknowledge OPFH Frugalia SL and Agroseguro SA for providing plant material used in this study.

${ }^{1}$ Corresponding author. E-mail: jrodrigo@aragon.es. different breeding programs (Okie and Hancock, 2008; Okie and Ramming, 1999).

The proportion of flowers that develop into fruit is much lower in japanese plum (Guerra et al., 2010) than in other Prunus species (Bradbury, 1929; Dicenta et al., 2002; Dorsey, 1919; Harrold, 1935; Hedhly et al., 2007; Kester and Griggs, 1959; Lech and Tylus, 1983; Rodrigo and Herrero, 2002a), but the higher number of flowers produced usually results in adequate fruit production (Hartmann and Neümuller, 2009; Okie, 2006). However, some japanese plum-type cultivars are particularly prone to erratic fruit set showing very low or even null fruit set for reasons that are not clear (Hartmann and Neümuller, 2009; Okie and Weinberger, 1996).

When no apparent adverse environmental conditions occur during flowering and fruit development, determining the biological causes for lack of fruit set is frequently difficult in fruit trees. In Prunus species, flowers have a unicarpellate gynoecium (Sterling, 1964). The ovary contains two ovules, and fertilization of at least one of them is required for fruit set, because Prunus species are unable to bear fruit parthenocarpically (Hartmann and Neümuller, 2009; Sedgley and Griffin, 1989). One of the two ovules, the primary ovule, continues 
growing in the days after anthesis and can be fertilized and become a seed; the other, the secondary ovule, arrests its growth and usually aborts. Thus, a number of factors intervene in the reproductive process leading to final fruit set. These include pollen viability, pollen transfer to the stigma, pollen-pistil incompatibility reaction, synchrony between pollen tube arrival to the ovule and embryo sac maturation, fertilization of at least one ovule, and successful early embryo development (Bradbury, 1929; Dorsey, 1919; Harrold, 1935; Hormaza and Herrero, 1996; Pimienta and Polito, 1982; Rodrigo and Herrero, 1998). Although these processes have been analyzed in different Prunus species, the reproductive behavior of japanese plum-type cultivars is not known, and this may be one of the reasons for the lack of fruit set obtained in some new cultivars (Okie, 2006).

Traditionally, the factors intervening in the reproductive process have not been considered as a cause of low fruit set in japanese plum, although some male sterile cultivars have been reported (Herrero and Salvador, 1980; Ramming, 1995). However, pollination factors have been related to fruit set in different cultivars and situations in the last years (Guerra, 2011; Jia et al., 2008; Sapir et al., 2008a, 2008b). Japanese plum, like other Prunus fruit tree species, exhibits gametophytic self-incompatibility, a widespread mechanism in flowering plants, which prevents selfpollination and, thus, promotes outcrossing (De Nettancourt, 2001). Although some self-compatible cultivars have been reported, most japanese plum-type cultivars are self-incompatible and need pollenizer cultivars coincident at flowering interplanted in the same orchard to ensure fruit set (Guerra, 2011; Guerra et al., 2009, 2010; Halász et al., 2007; Okie and Weinberger, 1996; Sapir et al., 2004).

'Angeleno', 'Rubirosa', and 'Sweet August' exhibit good production in some commercial orchards and seasons, but records of very low or null fruit set have been observed in some orchards. To ascertain the causes of lack of fruit set, the reproductive process has been evaluated in open-pollinated flowers of these cultivars (Angeleno, Rubirosa, and Sweet August) and compared with the producing cultivar Simka. To determine which factors that intervene in the reproductive process could be related to the lack of fruit set, microscopic observations of pollen grain germination, pollen tube growth, pollen-pistil incompatibility, and ovule development were analyzed in flowers from the three low-producing cultivars and the productive cultivar Simka. In 'Rubirosa' and 'Sweet August', for which no information about their pollen-pistil compatibility is available, self- and cross-pollinations were carried out in both orchard and laboratory conditions. Fruit set and fruit drop were followed until harvest in each pollination treatment.

\section{Materials and Methods}

Plant material. Three japanese plum-type cultivars with records of very low or null fruit set in previous seasons were analyzed. Cultivars Rubirosa and Sweet August were analyzed in an orchard located in Elvas, Portugal, and cultivar Angeleno in an orchard located in Villanueva de la Serena, Spain. These three low-producing cultivars were compared with the productive cultivar Simka located in Zaragoza, Spain. Three trees of each cultivar were used to evaluate the reproductive process and characterize their fruit set. Different cultivars coincident at flowering with the cultivars studied were evaluated as potential pollenizers in each orchard (Table 1).
Table 1. Location of the orchards studied and percentage of in vitro pollen germination of nine japanese plum-type cultivars.

\begin{tabular}{llc}
\hline Location & $\begin{array}{l}\text { Cultivars } \\
\text { analyzed }\end{array}$ & $\begin{array}{c}\text { Pollen viability } \\
(\% \pm \mathrm{SE})^{\mathrm{z}}\end{array}$ \\
\hline Elvas, Portugal & $\begin{array}{l}\text { Black Jewell } \\
\text { Sybarite } \\
\text { Sweet August } \\
\text { Champion }\end{array}$ & - \\
& Rubirosa & $19.1 \pm 2.1 \mathrm{~b}^{\mathrm{y}}$ \\
& Hiromi Red & $21.7 \pm 1.9 \mathrm{~b}$ \\
& Larry Ann & $30.7 \pm 1.3 \mathrm{c}$ \\
Villanueva de la & & $60.6 \pm 2.8 \mathrm{~d}$ \\
Serena, Spain & Songold & $31.0 \pm 2.2 \mathrm{c}$ \\
Zaragoza, Spain & Simka & $12.2 \pm 0.9 \mathrm{a}$ \\
& & $27.7 \pm 1.5 \mathrm{c}$ \\
Sample size (N) & & 42 \\
F statistic & & 63574 \\
df & & 6 \\
$P$ & & $<0.001$ \\
\hline
\end{tabular}

${ }^{\mathrm{z}}$ Mean \pm SE of six replicates.

${ }^{\mathrm{y}}$ Different letters indicate significant differences $(P<0.05)$ using Duncan's multiple range test.

Pollen viability. To identify adequate pollenizers, pollen viability of the cultivars studied and of potential pollenizers coincident at flowering in each location was evaluated: 'Black Jewell', 'Champion', 'Hiromi Red', 'Rubirosa', 'Sweet August', and 'Sybarite' in Elvas; 'Larry Ann' in Villanueva de la Serena; and 'Songold' and 'Simka' in Zaragoza (Table 1). Pollen was obtained from flowers of each cultivar collected at the balloon stage, to which anthers were removed and placed on paper at room temperature during $24 \mathrm{~h}$ until anther dehiscence. Pollen was then sieved through a $0.26-\mathrm{mm}$ mesh and stored at $-20{ }^{\circ} \mathrm{C}$ until required. Pollen was scattered on a solidified germination medium consisting of $0.3 \mathrm{M}$ sucrose, $0.6 \mathrm{~mm} \mathrm{Ca}\left(\mathrm{NO}_{3}\right)_{2}, 1.6 \mathrm{~mm}$ $\mathrm{H}_{3} \mathrm{BO}_{3}$, and $0.8 \%$ of agar (Hormaza et al., 1996) in polystyrene petri dishes $(60 \times 10 \mathrm{~mm})$. Pollen was germinated for $24 \mathrm{~h}$ at $20{ }^{\circ} \mathrm{C}$ and then frozen at $-20{ }^{\circ} \mathrm{C}$ to arrest pollen germination. Preparations were thawed during $24 \mathrm{~h}$ at $4{ }^{\circ} \mathrm{C}$, stained with $1 \%$ (v/v) aniline blue in $0.1 \mathrm{~N} \mathrm{~K}_{3} \mathrm{PO}_{4}$ to stain callose (Linskens and Esser, 1957), and observed under a fluorescence microscope (DM2500; Leica Microsystems, Wetzlar, Germany) equipped with ultraviolet epifluorescence with a BP340-390 exciter filter and a LP 425 barrier filter (Leica Microsystems). A pollen grain was considered viable when its growing pollen tube was longer than the pollen grain diameter (Fig. 1A). Viability was recorded in two petri dishes for each cultivar by counting viable and nonviable pollen grains in three fields per plate, each field containing 100 to 200 pollen grains. From these data (six replicates) the percentage of viable pollen grains of each cultivar was estimated.

Fruit SET AND POLLEN TRANSFER IN ORCHARD CONDITIONS. A group of flowers (439 to 1555) from each cultivar studied (Angeleno, Rubirosa, Sweet August, and Simka) were left untreated for open pollination (Table 2). Weekly counts of flowers and developing fruit from anthesis to harvest were carried out to ascertain final fruit set.

To study if pollen was correctly transferred to the pistils in orchard conditions, pollen arrival and germination at the stigma was evaluated in 40 to 50 open-pollinated flowers for each cultivar. Flowers were collected at the petal fall stage and fixed in alcohol:acetic acid (3:1) (Williams et al., 1999). For microscope 

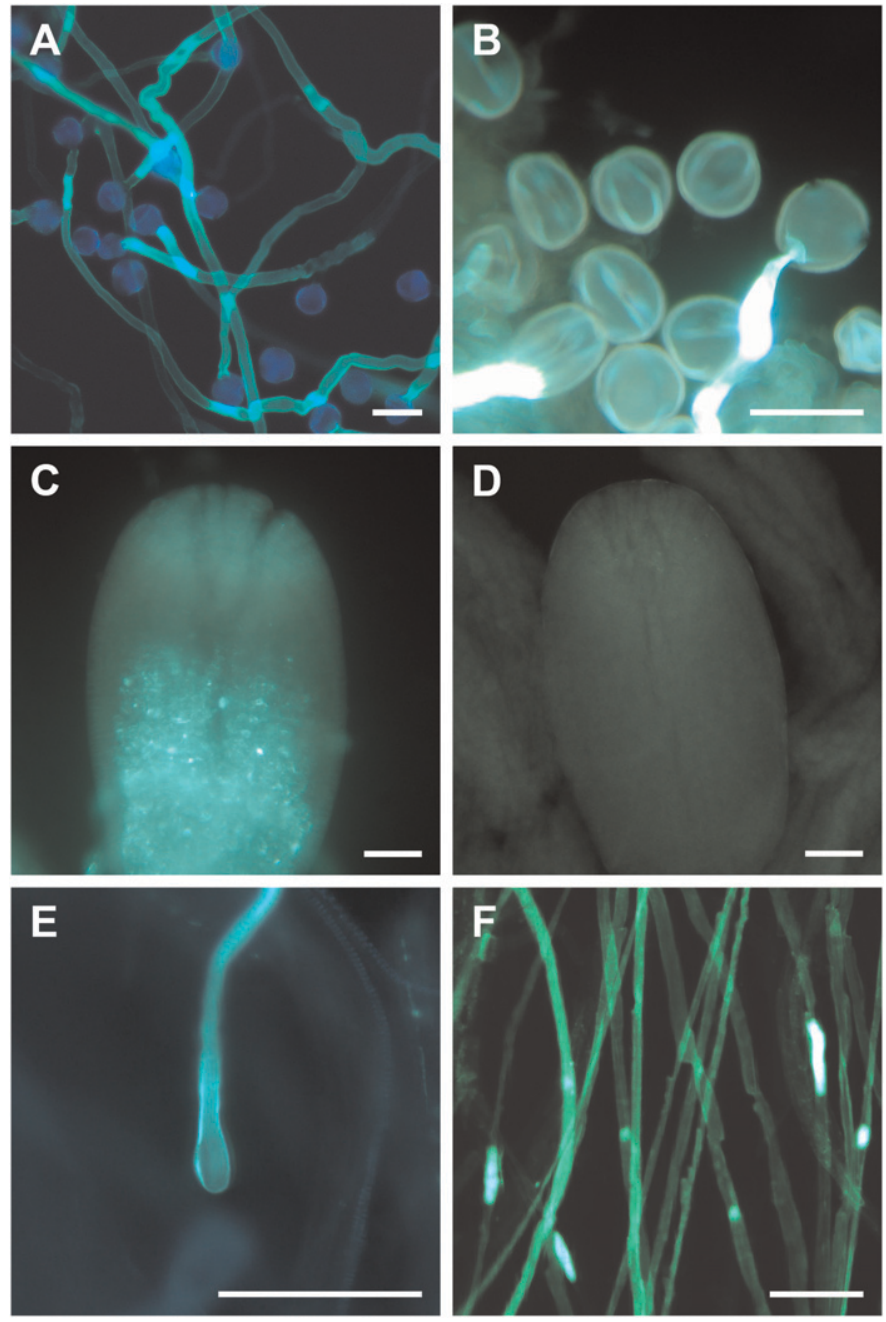

Fig. 1. Pollen germination, pollen tube growth, and ovule development in japanese plum flowers. Pollen grain germination (A) in vitro and (B) at the stigma. (C) Degenerated ovule with callose accumulation at the chalazal end. (D) Well-developed ovule. (E) Pollen tube arrested in the style in an incompatible cross. (F) Pollen tubes advancing to the base of the style in a compatible cross; bars $=50 \mu \mathrm{m}$.

preparation, the fixed pistils were washed three times for $1 \mathrm{~h}$ with distilled water and left $24 \mathrm{~h}$ in $5 \%(\mathrm{w} / \mathrm{v})$ sodium sulphite at $4{ }^{\circ} \mathrm{C}$. The next day, the pistils were autoclaved during $8 \mathrm{~min}$ at 1 $\mathrm{kg} \cdot \mathrm{cm}^{-2}$ in $5 \%$ sodium sulphite to soften the tissues (Jefferies and Belcher, 1974). Pollen grains were monitored on squash preparations of stigmas and styles (Rodrigo et al., 2009) with the same staining procedure used to determine pollen viability and observed under a microscope (BH2; Olympus Optical Co., Tokyo, Japan) with ultraviolet epifluorescence using a BP 355/ 425 exciter filter and a LP 470 barrier filter. The percentage of flowers with more than 30 germinated pollen grains in the stigma was calculated for each cultivar.

Self-incompatibility. 'Angeleno' is self-incompatible and 'Simka' is self-compatible (Guerra et al., 2009), but no information of pollen-pistil incompatibility is available regarding 'Rubirosa' and 'Sweet August'. Thus, self-incompatibility was analyzed by hand self-pollinations carried out both in the field and the laboratory and evaluated as the possible cause for lack of fruit set in 'Rubirosa' and 'Sweet August'. The same analysis was carried out in the self-compatible cultivar Simka.
Because emasculation of flowers has been related to lack of fruit set in different japanese plum-type cultivars, self-pollinations in the field were performed in non-emasculated flowers by supplementary pollination in caged trees (Guerra et al., 2010). For this purpose, two trees of 'Sweet August', 'Rubirosa', and 'Simka' were enclosed in $0.8-\mathrm{mm}$ mesh cages before bloom to avoid the arrival of pollinator insects. Pollinations were done by hand using a thin paintbrush every other day until all flowers had opened (Rodrigo and Herrero, 2002b). Pollen used in each pollination treatment was obtained following the method described previously. Self-pollinations were carried out in selected branches in the caged trees by self-pollinating 950 to 1500 flowers of each cultivar (Table 2). Fruit set were established following the same method described for open pollinations.

Self-pollinations were also performed in the laboratory and analyzed by the observation of pollen tube growth along the style of the flower under the microscope. Flowers from each cultivar were collected at the balloon stage, emasculated, and maintained on wet florist foam at room temperature (Rodrigo and Herrero, 1996). Thirty flowers per treatment were handpollinated $24 \mathrm{~h}$ after emasculation with pollen of the same cultivar obtained following the method described previously. Seventy-two h later, when pollen tubes were expected to arrive at the base of the style (Guerra et al., 2009), the pistils were fixed and monitored to pollen tube observation with the same staining procedure used to observe pollen germination. The number of pollen tubes at the base of the style was recorded in at least 10 pistils per cultivar (Table 3 ).

Cross-incompatibility. Cross-incompatibility of 'Rubirosa' and 'Sweet August' with the cultivars coincident at flowering was investigated by crosses carried out in the field and the laboratory following the methods described for self-pollinations and compared with 'Simka' pollinated with the compatible pollenizer 'Songold' (Tables 2 and 3). Because errors in the nomenclature of some japanese plum-type cultivars have been detected in several commercial orchards in Spain (Guerra, 2011), $S$-RNase typing was carried out in all the cultivars studied to study their cross-(in)compatibility and to confirm cultivar identity. For this purpose, genomic DNA from the cultivars analyzed was isolated from young leaves following the protocol described by Hormaza (2002). S-RNase typing was carried out by $S$-RNase polymerase chain reaction (PCR) amplification using primers pairs Pru C2-PCER, and Pru T2-PCER (Tao et al., 1999; Yamane et al., 2001) according to Guerra et al. (2009) (Table 3).

Ovule DeVelopment. From each cultivar and pollination treatment in the field, ovule development was examined under the microscope on squash preparations in at least 10 pistils per pollination treatment (Table 2). Ovules were scored for ovule viability through the presence of callose deposits in the chalaza of degenerating ovules (Guerra et al., 2010). Ovule development was monitored with the same staining procedure used to observe pollen germination and pollen tube growth. Preparations were observed under a Leica DM2500 fluorescence microscope equipped with ultraviolet epifluorescence with a BP340-390 exciter filter and a LP 425 barrier filter.

STATiSTiCAL ANALySES. Statistical analyses were performed with SPSS statistical software (Version 15.0; SPSS, Chicago, IL). One-way analysis of variances (ANOVA) was performed to analyze pollen germination, in which germination percentage data were subjected to arcsine root square transformation. When ANOVA generated significant differences $(P<0.05)$, 
Table 2. Japanese plum-type cultivars studied by open-, self-, and cross-pollination under orchard conditions. ${ }^{\mathrm{z}}$

\begin{tabular}{|c|c|c|c|c|c|}
\hline $\begin{array}{l}\text { Cultivar/Pollination } \\
\text { treatment }\end{array}$ & $\begin{array}{c}\text { Pistils with } \\
\text { germinated pollen } \\
\text { grains }(\%)\end{array}$ & $\begin{array}{c}\text { Flowers } \\
\text { (no.) }\end{array}$ & $\begin{array}{l}\text { Fruit } \\
\text { (no.) }\end{array}$ & $\begin{array}{c}\text { Fruit } \\
\text { set }(\%) \\
\end{array}$ & $\begin{array}{c}\text { Pistils with } \\
\text { both ovules } \\
\text { degenerated (\%) } \\
\end{array}$ \\
\hline \multicolumn{6}{|l|}{ Sweet August } \\
\hline Open-pollination & $67 \mathrm{a}^{\mathrm{y}}$ & 1,555 & 0 & $0 \mathrm{a}$ & $100 \mathrm{~d}$ \\
\hline Self-pollination & & 1,322 & 0 & $0 \mathrm{a}$ & $80 \mathrm{bc}$ \\
\hline$\times$ Champion & & 1,382 & 10 & $0.7 \mathrm{ab}$ & $71 \mathrm{bc}$ \\
\hline$\times$ Rubirosa & & 1,471 & 19 & $1.3 \mathrm{~b}$ & $73 \mathrm{bc}$ \\
\hline \multicolumn{6}{|l|}{ Rubirosa } \\
\hline Open-pollination & $100 \mathrm{~b}$ & 1,516 & 0 & $0 \mathrm{a}$ & $71 \mathrm{bc}$ \\
\hline Self-pollination & & 959 & 0 & $0 \mathrm{a}$ & $50 \mathrm{~b}$ \\
\hline$\times$ Champion & & 1,084 & 0 & $0 \mathrm{a}$ & $75 \mathrm{bc}$ \\
\hline$\times$ Hiromi Red & & 943 & 5 & $0.5 \mathrm{ab}$ & $50 \mathrm{~b}$ \\
\hline \multicolumn{6}{|l|}{ Angeleno } \\
\hline Open-pollination & $94.4 \mathrm{~b}$ & 439 & 1 & $0.5 \mathrm{ab}$ & $92 \mathrm{bc}$ \\
\hline \multicolumn{6}{|l|}{ Simka } \\
\hline Open-pollination & $100 \mathrm{~b}$ & 1,442 & 87 & $6 \mathrm{~d}$ & $0 \mathrm{a}$ \\
\hline Self-pollination & & 1,519 & 57 & $4 \mathrm{c}$ & $0 \mathrm{a}$ \\
\hline$\times$ Songold & & 1,472 & 79 & $5 \mathrm{~d}$ & $0 \mathrm{a}$ \\
\hline Sample size $(\mathrm{N})$ & 75 & & & 15,097 & 94 \\
\hline df & 3 & & & 11 & 11 \\
\hline Pearson chi square & 9834 & & & 454,159 & 62,059 \\
\hline$P$ & 0.02 & & & $<0.001$ & $<0.001$ \\
\hline
\end{tabular}

$\overline{{ }^{z} \text { Pollen transfer, number of flowers, number of fruit, percentage of fruit set, and percentage }}$ of pistils with both ovules degenerated in the different pollination treatments.

${ }^{\mathrm{y}}$ Within a column, different letters indicate significant differences $(P<0.05)$ using two-way contingency tables followed by Pearson's chi-square test of independence for categorical variables with Yates' correction for continuity or the Fisher's exact test as appropriate. mean separations were determined by Duncan's multiple range test.

Pearson's chi-square test of independence for categorical variables was performed to analyze the percentages of fruit set in openand hand-pollinations, pistils with pollen grains germinated at the stigma in openpollinated flowers, pistils with pollen tubes at the base of the style in hand-pollinated flowers, and pistils with both ovules degenerated in flowers from all pollination treatments. When Pearson's chi-square test of independence generated significant differences $(P<0.05)$, percentage separations were determined by chi-square test of independence in two-way contingency tables generated for each pairwise comparison with Yates' correction for continuity. In those cases in which expected cell frequencies were low, Fisher's exact test was implemented.

\section{Results}

Two cultivars appeared to be male-sterile and therefore were not further used in pollination experiments. 'Black Jewell' did not have pollen grains in the anthers, and 'Sybarite' displayed very few pollen grains with a very low percentage of pollen germination. Pollen viability, evaluated through in vitro pollen germination (Fig. 1A), differed significantly between the other cultivars analyzed (Table 1), ranging from $12.2 \%$ to $60.6 \%$ in 'Hiromi Red', 'Larry Ann', 'Rubirosa', 'Songold', 'Sweet August', and 'Simka', and these cultivars were considered as pollenizers.

To analyze if pollen was correctly transferred to the pistils, randomly fixed flowers from open-pollinated flowers were observed under the microscope. Pollen transfer was assessed through the presence of pollen at the stigma. Most openpollinated flowers in the four cultivars analyzed showed germinated pollen grains at the stigma (Fig. 1B; Table 2).

Significant differences between the percentages of fruit set were observed for the different pollination treatments. Open pollination resulted in lack of fruit set for 'Rubirosa', 'Sweet August', and 'Angeleno' (Table 2). Self-pollination also resulted in lack of fruit set in 'Rubirosa' and 'Sweet August' (Table 2). In the cross-pollinations, 'Rubirosa' and 'Sweet August' also displayed very low fruit set, ranging from $0 \%$ to $1.3 \%$ (Table 2 ). On the other hand, fruit set in 'Simka' ranged from $4 \%$ to $6 \%$ in the different pollination treatments (Table 2).

Ovule development was analyzed under the microscope in pistils from all cultivars and pollination treatments performed in the field. Both ovules were degenerated showing callose in the chalaza (Fig. 1C) in a variable percentage (50\% to $100 \%)$ of flowers of 'Angeleno', 'Rubirosa', and 'Sweet August' from all pollination treatments in the field (Table 2). However, all the pistils from the productive cultivar Simka presented at least one ovule well developed with no callose in the chalaza (Fig. 1D; Table 2). No differences in size were observed between degenerated and non-degenerated ovules (Fig. 1C-D). Chi-square analysis revealed significant differences between the percentages 
of pistils with both ovules degenerated for the different pollination treatments (Table 2).

To evaluate if the lack of fruit set was the result of pollenpistil incompatibility, self- and cross-incompatibility were analyzed by the observation of pollen tube growth through the style in pistils of self- and cross-pollinated flowers in the laboratory. Chi-square analysis revealed significant differences between the percentages of pistils with pollen tubes at the base of the style for the different crosses (Table 3). In all self-pollinated flowers of 'Sweet August', pollen tube growth was arrested in the style and no pollen tubes reached the base of the style (Fig. 1E; Table 3), indicating that this cultivar is self-incompatible. On the other side, a variable percentage of pistils of 'Rubirosa' (36\%) and 'Simka' (33\%) showed pollen tubes growing along the style (Fig. $1 \mathrm{~F})$ and reaching the ovary after self-pollination, indicating selfcompatibility in both cultivars (Table 3 ).

$S$-RNase typing by PCR showed that most combinations between cultivars coincident at flowering in each orchard had at least one different $S$-allele and therefore were cross-compatible, and only the cross 'Rubirosa' $\times$ 'Champion' was expected to be cross-incompatible because both cultivars had the same $S$-genotype (Table 3). Additionally, to confirm the results obtained by PCR, pollen tube growth was observed in flowers from some crosses. Cross-pollinations displayed variable percentages of pistils with pollen tubes reaching the base of the style. Whereas some pistils of the crosses 'Sweet August' $\times$ 'Champion', 'Sweet August' $\times$ 'Rubirosa', 'Rubirosa' $\times$ 'Hiromi Red', and 'Simka' $\times$ 'Songold' had pollen tubes at the base of the style, pollen tubes did not reach the base of the style in the pistils analyzed from the cross 'Rubirosa' $\times$ 'Champion' (Table 3 ). Thus, all the crosses analyzed under the microscope were compatible except 'Rubirosa' $\times$ 'Champion' that was incompatible.

\section{Discussion}

The study of different factors intervening in the reproductive process allowed dismissal of pollen viability, pollen transfer, and pollen-pistil incompatibility as the cause of lack of fruit set in the three low producing japanese plum-type cultivars evaluated. However, premature degeneration of the ovules was identified as the factor causing female sterility and therefore lack of fruit set in these cultivars and orchards.

The percentage of fruit set in 'Angeleno', 'Rubirosa', and 'Sweet August' was very low or null and lower than expected for japanese plum in orchard conditions, which usually ranges from $2 \%$ to $6 \%$ depending on cultivars (Guerra, 2011; Guerra et al., 2010; Jia et al., 2008), thus reflecting the records of lack of fruit set for these cultivars in the orchards analyzed in previous seasons.

'Black Jewell' and 'Sybarite' behaved as male-sterile and thus were not considered as pollenizers. Male sterility has been reported in japanese plum cultivars like First Beaut (Ramming, 1995) or Red Beaut (Herrero and Salvador, 1980) and in different offsprings (Ontivero et al., 2006). Whereas 'Black Jewell' did not show pollen grains in the anthers as 'Red Beaut' (Herrero and Salvador, 1980), 'Sybarite' had some few pollen grains but with very low viability. Although these two potential pollenizer cultivars were male-sterile, other cultivars in the same orchard were coincident at flowering with 'Rubirosa' and 'Sweet August' and had viable pollen that was adequately transferred to the stigmas. In the other orchard, 'Larry Ann' coincided at flowering with 'Angeleno', and its pollen was also viable and well transferred to the flowers of 'Angeleno'. Therefore, pollen viability and pollen transfer did not seem to affect the lack of fruit set in the three low-producing cultivars analyzed.

'Angeleno' is self-incompatible (Guerra et al., 2009) and 'Sweet August' also behaved as self-incompatible, because no pollen tubes were observed at the base of the style in selfpollinated flowers. On the other hand, some pistils of 'Rubirosa' showed pollen tubes reaching the ovary; thus, 'Rubirosa' appeared to also be self-compatible. The observation of pollen tube growth and $S$-allele typing by PCR showed that 'Angeleno', 'Rubirosa', and 'Sweet August' had at least one compatible pollenizer cultivar coincident at flowering in each orchard, which allowed dismissing cross-incompatibility as the cause of the lack of fruit set.

The $S$-RNase genotypes of 'Black Jewell' ( $S b S e)$, 'Champion' $(\mathrm{ScSe})$, 'Rubirosa' $(\mathrm{ScSe})$, 'Sweet August' ( $\mathrm{ScSh}$ ), and 'Sybarite' $(\mathrm{ScSe})$ are reported for the first time in this study, and the S-RNase genotypes of 'Angeleno', 'Hiromi Red', 'Larry Ann', 'Simka', and 'Songold' agree with previous studies (Beppu et al., 2003; Guerra et al., 2009; Sapir et al., 2008a).

The crossings followed by observation of pollen tube growth confirmed that 'Rubirosa' is compatible with 'Hiromi Red' and incompatible with 'Champion' and that 'Sweet August' is compatible with 'Champion' and 'Rubirosa'. These results are expected because the cultivars had different $S$-genotypes in the compatible crosses ('Rubirosa' $\times$ 'Hiromi Red', 'Sweet August' $\times$ 'Champion', and 'Sweet August' $\times$ 'Rubirosa') and the same $S$-genotype in the incompatible cross ('Rubirosa' $\times$ 'Champion'). However, it is surprising that this cross appeared to be incompatible given that 'Rubirosa' seems to be selfcompatible and has the $\mathrm{Se}$-allele, which has been related to selfcompatibility (Beppu et al., 2005, 2010). Self-compatibility of the $S e$ allele is caused by breakdown of the pistil function of the self-incompatible reaction (Watari et al., 2007). If selfcompatibility of 'Rubirosa' was the result of breakdown of pistil function, it should be compatible when pollinated with pollen of the cultivar Champion. However, this cross was incompatible in this work. These results indicate that self-compatibility in 'Rubirosa' must be the result of a different type of selfcompatibility. Further research will be needed to characterize this type of self-compatibility and to determine cross-compatibility with other japanese plum-type cultivars. Cross-incompatibility of self-compatible cultivars with cultivars with the same $S$-genotype has been described in Prunus species other than japanese plum, like sweet cherry [Prunus avium (Sonneveld et al., 2005; Wünsch and Hormaza, 2004)] and apricot [Prunus armeniaca (Vilanova et al., 2006; Wu et al., 2011)]. On the other hand, the fact that most japanese plum-type cultivars are complex hybrids resulted from the hybridization of more than two diploid plum species (Byrne, 1989; Faust and Surányi, 1999; Okie, 2006) suggests that a interspecific incongruity reaction rather than a pollen-pistil incompatibility reaction could also be taking place between some cultivars.

Flower and fruit abscission results from a number of events that take place during flower differentiation (Julian et al., 2010), the progamic phase (Rodrigo and Herrero, 2002b), and early fruit development (Alcaraz et al., 2010). Once other factors involved in the reproductive process were eliminated, ovule development was assessed in flowers from each treatment. The presence of degenerated ovules in flowers from open- and 
hand-pollinations resulted in no fruit set and the absence of degenerated ovules in flowers from fruit-setting open- and handpollinations allowed identifying ovule degeneration as one of the major causes of lack of fruit set in the three low-producing cultivars analyzed in both orchards. Most flowers of 'Angeleno', 'Rubirosa', and 'Sweet August' showed both ovules degenerated and therefore fertilization could not take place. However, all the flowers of the producing cultivar Simka had at least one welldeveloped ovule.

In other Prunus species, degeneration of the secondary ovule has been related to the accumulation of callose from the chalazal end of the nucellus to the whole ovule, which then shows clear symptoms of degeneration with a shrunken nucellus (Arbeloa and Herrero, 1991; Cerović and Mićić, 1999; Cerović et al., 2000; Guerra et al., 2010; Pimienta and Polito, 1982; Rodrigo and Herrero, 1998; Stösser and Anvari, 1982). Although the premature degeneration of one of the two ovules is part of the normal developmental process of Prunus flowers, the degeneration of both ovules in flowers has been associated with female sterility in different Prunus species and cultivars. The implications of female sterility in Prunus are more serious than those of male sterility. Male-sterile cultivars can set fruit with pollen from other cultivars, but female-sterile cultivars cannot set fruit because they are not parthenocarpic (Hartmann and Neümuller, 2009; Sedgley and Griffin, 1989). Although female sterility is selected against in breeding, it has been reported in other Prunus cultivars, but it is not clear what factors can be involved in the premature degeneration of the ovules. Female sterility has been considered as a varietal characteristic in sweet cherry '0900 Ziraat' (Mert and Soylu, 2007). However, the three japanese plum-type cultivars analyzed here usually produce adequately in other orchards, and therefore female sterility can be dismissed as a genetic characteristic in these cases. In apricot 'Trevatt Blue', female sterility has been attributed to a possible mutation in the original cultivar tree from which the budwood was taken to be clonally propagated (Lillecrapp et al., 1999). This could explain the situation recorded here, although it seems unlikely that it would occur simultaneously in three different cultivars located in two different orchards. Therefore, it seems more likely that it can be caused by external factors.

Female sterility resulting in a reduction of fruit set in other Prunus species has been related to adverse environmental conditions such as spring frosts (Rodrigo, 2000) or high temperatures before (Rodrigo and Herrero, 2002b) and after flowering (Hedhly et al., 2007, 2009). The fact that both degenerated and non-degenerated ovules showed the same size at anthesis could indicate that flowers were affected in the immediate previous days. However, no adverse environmental conditions were recorded during flower development in the cultivars and orchards under study. Female sterility has been also related to excess of pollen on the stigma in sensitive walnut (Juglans regia) cultivars (McGranahan et al., 1994). When pollen arrives on the stigma, it induces ethylene production (Johnson and Polito, 2007), which has been reported to induce the arrest of ovule development (Zhang and O'Neill, 1993). Female sterility in Prunus can be also induced by the application of different external chemical treatments (Beppu et al., 2001; Herrero et al., 2000; Morenol et al., 1992; Stösser and Anvari, 1982). Regardless of the factor causing ovule degeneration, it seems that different genotypes have a different response, because in one of the orchards analyzed, other cultivars had normal fruit sets (data not shown).
Results here revealed a high incidence of premature ovule degeneration on final fruit set in the three cultivars analyzed. The lack of fruit set in orchards with no apparent adverse environmental conditions is traditionally addressed by analyzing either the pollination process or the pollen-pistil incompatibility relationships. However, the stage of development of the ovules and their viability are not usually considered. The approach used in this work may prove valuable to other species and situations of lack of fruit set, which could help to identify the causes for premature ovule degeneration.

\section{Literature Cited}

Alcaraz, M.L., J.I. Hormaza, and J. Rodrigo. 2010. Ovary starch reserves and pistil development in avocado (Persea americana). Physiol. Plant. 140:395-404.

Arbeloa, A. and M. Herrero. 1991. Development of the ovular structures in peach. [Prunus persica (L.) Batsch]. New Phytol. 118:527-533.

Beppu, K., N. Komatsu, H. Yamane, H. Yaegaki, M. Yamaguchi, R. Tao, and I. Kataoka. 2005. Se-haplotype confers self-compatibility in japanese plum (Prunus salicina Lindl.). J. Hort. Sci. Biotechnol. 80:760-764.

Beppu, K., T. Suehara, and I. Kataoka. 2001. Embryo sac development and fruit set of 'Satonishiki' sweet cherry as affected by temperature, GA3 and paclobutrazol. J. Jpn. Soc. Hort. Sci. 70:157-162.

Beppu, K., K. Syogase, H. Yamane, R. Tao, and I. Kataoka. 2010. Inheritance of self-compatibility conferred by the Se-haplotype of japanese plum and development of Se RNase gene-specific PCR primers. J. Hort. Sci. Biotechnol. 85:215-218.

Beppu, K., Y. Takemoto, H. Yamane, H. Yaegaki, M. Yamaguchi, I. Kataoka, and R. Tao. 2003. Determination of $S$-haplotypes of japanese plum (Prunus salicina) cultivars by PCR and crosspollination test. J. Hort. Sci. Biotechnol. 78:315-318.

Bradbury, D. 1929. A comparative study of the developing and aborting fruits of Prunus cerasus. Amer. J. Bot. 16:525-531.

Byrne, D.H. 1989. Inbreeding, coancestry, and founding clones of japanese-type plums of California and the southeastern United States. J. Amer. Soc. Hort. Sci. 114:699-705.

Cerović, R. and N. Mićić. 1999. Functionality of embryo sacs as related to their viability and fertilization success in sour cherry. Sci. Hort. 79:227-235.

Cerović, R., D. Ružić, and N. Mićić. 2000. Viability of plum ovules at different temperatures. Ann. Appl. Biol. 137:53-58.

De Nettancourt, D. 2001. Incompatibility and incongruity in wild and cultivated plants. Springer, Berlin, Germany.

Dicenta, F., E. Ortega, J.A. Cánovas, and J. Egea. 2002. Selfpollination vs. cross-pollination in almond: Pollen tube growth, fruit set and fruit characteristics. Plant Breed. 121:163-167.

Dorsey, M.J. 1919. A study of sterility in the plum. Genetics 4:417489.

Faust, M. and D. Surányi. 1999. Origin and dissemination of plums. Hort. Rev. 23:179-231.

Guerra, M.E. 2011. Polinización y cuajado en ciruelo japonés. PhD diss., Extremadura Univ., Badajoz, Spain.

Guerra, M.E., J. Rodrigo, M. López-Corrales, and A. Wünsch. 2009. $S$-RNase genotyping and incompatibility group assignment by PCR and pollination experiments in japanese plum. Plant Breed. 128: 304-311.

Guerra, M.E., A. Wünsch, M. López-Corrales, and J. Rodrigo. 2010. Flower emasculation as the cause for lack of fruit set in japanese plum crosses. J. Amer. Soc. Hort. Sci. 135:556-562.

Halász, J., A. Hegedűs, Z. Szabó, J. Nyéki, and A. Pedryc. 2007. DNAbased S-genotyping of japanese plum and pluot cultivars to clarify incompatibility relationships. HortScience 42:46-50.

Harrold, T.J. 1935. Comparative study of the developing and aborting fruits of Prunus persica. Bot. Gaz. 96:505-520. 
Hartmann, W. and M. Neümuller. 2009. Plum breeding, p. 161-231. In: Jain, S.M., and P.M. Priyadarshan (eds.). Breeding plantation tree crops: Temperate species. Springer Science, Stuttgart, Germany.

Hedhly, A., J.I. Hormaza, and M. Herrero. 2007. Warm temperatures at bloom reduce fruit set in sweet cherry. J Appl. Bot. Food QualityAngewandte Botanik 81:158-164.

Hedhly, A., J.I. Hormaza, and M. Herrero. 2009. Flower emasculation accelerates ovule degeneration and reduces fruit set in sweet cherry. Sci. Hort. 119:455-457.

Herrero, M., J. Rodrigo, and J.I. Hormaza. 2000. Modo de acción del Armothin como aclarante de 'Catherina'. Información Técnica Económica Agraria 21:95-99.

Herrero, M. and J. Salvador. 1980. La polinización del ciruelo Red Beaut. Información Técnica Económica Agraria 41:3-7.

Hormaza, J.I. 2002. Molecular characterization and similarity relationships among apricot (Prunus armeniaca L.) genotypes using simple sequence repeats. Theor. Appl. Genet. 104:321-328.

Hormaza, J.I. and M. Herrero. 1996. Dynamics of pollen tube growth under different competition regimes. Sex. Plant Reprod. 9:153-160. Hormaza, J.I., K. Pinney, and V.S. Polito. 1996. Correlation in the tolerance to ozone between sporophytes and male gametophytes of several fruit and nut tree species (Rosaceae). Sex. Plant Reprod. 9:44-48.

Jefferies, C.J. and A.R. Belcher. 1974. Fluorescent brightener used for pollen-tube identification in vivo. Stain Technol. 49:199-202.

Jia, H.J., F.J. He, C.Z. Xiong, F.R. Zhu, and G. Okamoto. 2008. Influences of cross pollination on pollen tube growth and fruit set in Zuili plums (Prunus salicina). J. Integr. Plant Biol. 50:203-209.

Johnson, H. and V. Polito. 2007. Pistillate flower abortion and pollination-induced ethylene production in english walnut. HortScience 42:865 (abstr.).

Julian, C., M. Herrero, and J. Rodrigo. 2010. Flower bud differentiation and development in fruiting and non-fruiting shoots in relation to fruit set in apricot (Prunus armeniaca L.). Trees (Berl.) 24:833-841.

Kester, D.E. and W.H. Griggs. 1959. Fruit setting in the almond: The pattern of flower and fruit drop. Proc. Amer. Soc. Hort. Sci. 74:214-219. Lech, W. and K. Tylus. 1983. Pollination, fertilization and fruit setting of some sour cherry varieties. Acta Hort. 139:33-39.

Lillecrapp, A.M., M.A. Wallwork, and M. Sedgley. 1999. Female and male sterility cause low fruit set in a clone of the 'Trevatt' variety of apricot (Prunus armeniaca). Sci. Hort. 82:255-263.

Linskens, H.F. and K. Esser. 1957. Über eine spezifische Anfärbung der Pollen-Shläuche und die Zagl Kallosapropten nach Selbstung und Fremdung. Naturwissenschaften 44:16.

McGranahan, G.H., D.G. Voyiatzis, P.B. Catlin, and V. Polito. 1994. High pollen loads can cause pistillate flower abscission in walnut. J. Amer. Soc. Hort. Sci. 119:505-509.

Mert, C. and A. Soylu. 2007. Possible cause of low fruit set in the sweet cherry cultivar 0900 Ziraat. Can. J. Plant Sci. 87:593-594.

Morenol, Y.M., A.N. Miller-Azarenko, and W. Potts. 1992. Genotype, temperature, and fall-applied ethephon affect plum flower bud development and ovule longevity. J. Amer. Soc. Hort. Sci. 117:14-21.

Okie, W.R. 2006. Introgression of Prunus species in plum. New York Fruit Qrtly. 14:29-37.

Okie, W.R. and J.F. Hancock. 2008. Plums, p. 337-356. In: Hancock, J.F. (ed.). Temperate fruit crop breeding. Springer, New York, NY.

Okie, W.R. and D.W. Ramming. 1999. Plum breeding worldwide. HortTechnology 9:162-176.

Okie, W.R. and J.H. Weinberger. 1996. Plums, p. 559-607. In: Janick, J. and J.N. Moore (eds.). Fruit breeding. Wiley, New York, NY.

Ontivero, M., S. Radice, E. Giordani, and E. Bellini. 2006. Effects of different pollination treatments in genotypes of Prunus salicina Lindl. Intl. J. Hort. Sci. 12:141-146.

Pimienta, E. and V.S. Polito. 1982. Ovule abortion in Nonpareil almond (Prunus dulcis Mill.Webb, D.A). Amer. J. Bot. 69:913-920.
Ramming, D.W. 1995. Plum. Register of new fruit and nut varieties. Brooks and Olmo. List 37. HortScience 30:1142-1144.

Rodrigo, J. 2000. Spring frost in deciduous fruit trees-Morphological damage and flower hardiness. Sci. Hort. 85:155-173.

Rodrigo, J. and M. Herrero. 1996. Evaluation of pollination as the cause of erratic fruit set in apricot 'Moniqui'. J. Hort. Sci. 71:801-805.

Rodrigo, J. and M. Herrero. 1998. Influence of intraovular reserves on ovule fate in apricot (Prunus armeniaca L.). Sex. Plant Reprod. 11: 86-93.

Rodrigo, J. and M. Herrero. 2002a. Effects of pre-blossom temperatures on flower development and fruit set in apricot. Sci. Hort. 92: $125-135$.

Rodrigo, J. and M. Herrero. 2002b. The onset of fruiting in apricot (Prunus armeniaca L.). J. Appl. Bot.-Angewandte Botanik. 76:13-19. Rodrigo, J., M. Herrero, and J.I. Hormaza. 2009. Pistil traits and flower fate in apricot (Prunus armeniaca). Ann. Appl. Biol. 154:365-375.

Sapir, G., R. Stern, S. Shafir, and M. Goldway. 2008b. Full compatibility is superior to semi-compatibility for fruit set in japanese plum (Prunus salicina Lindl.) cultivars. Sci. Hort. 116:394-398.

Sapir, G., R. Stern, S. Shafir, and M. Goldway. 2008a. S-RNase based $S$-genotyping of japanese plum (Prunus salicina Lindl.) and its implication on the assortment of cultivar-couples in the orchard. Sci. Hort. 118:8-13.

Sapir, G., R.A. Stern, D. Eisikowitch, and M. Goldway. 2004. Cloning of four new japanese plum $S$-alleles and determination of the compatibility between cultivars by PCR analysis. J. Hort. Sci. Biotechnol. 79:223-227.

Sedgley, M. and A.R. Griffin. 1989. Sexual reproduction of tree crops. Academic Press, London, UK.

Sonneveld, T., K.R. Tobutt, S.P. Vaughan, and T.P. Robbins. 2005. Loss of pollen- $S$ function in two self-compatible selections of Prunus avium is associated with deletion/mutation of an $S$ haplotype-specific F-box gene. Plant Cell 17:37-51.

Sterling, C. 1964. Comparative morphology of the carpel in the Rosaceae. 1. Prunoideae: Prunus. Amer. J. Bot. 51:36-44.

Stösser, R. and S.F. Anvari. 1982. On the senescence of ovules in cherries. Sci. Hort. 16:29-38.

Tao, R., H. Yamane, A. Sugiura, H. Murayama, H. Sassa, and H. Mori. 1999. Molecular typing of $S$-alleles through identification, characterization and cDNA cloning for $S-R N a s e s$ in sweet cherry. J. Amer. Soc. Hort. Sci. 124:224-233.

Vilanova, S., M.L. Badenes, L. Burgos, J. Martinez-Calvo, G. Llacer, and C. Romero. 2006. Self-compatibility of two apricot selections is associated with two pollen-part mutations of different nature. Plant Physiol. 142:629-641.

Watari, A., T. Hanada, H. Yamane, T. Esumi, R. Tao, H. Yaegaki, M. Yamaguchi, K. Beppu, and I. Kataoka. 2007. A low transcriptional level of S-e-RNase in the S-e-haplotype confers self-compatibility in japanese plum. J. Amer. Soc. Hort. Sci. 132:396-406.

Williams, J.H., W.E. Friedman, and M.L. Arnold. 1999. Developmental selection within the angiosperm style: Using gamete DNA to visualize interspecific pollen competition. Proc. Natl. Acad. Sci. USA 96:9201-9206.

Wu, J., C. Gu, Y.H. Du, H.Q. Wu, W.S. Liu, N. Liu, J. Lu, and S.L. Zhang. 2011. Self-compatibility of 'Katy' apricot (Prunus armeniaca L.) is associated with pollen-part mutations. Sex. Plant Reprod. 24:23-35.

Wünsch, A. and J.I. Hormaza. 2004. Genetic and molecular analysis in Cristobalina sweet cherry, a spontaneous self-compatible mutant. Sex. Plant Reprod. 17:203-210.

Yamane, H., R. Tao, A. Sugiura, N.R. Hauck, and A.F. Iezzoni. 2001. Identification and characterization of S-RNases in tetraploid sour cherry (Prunus cerasus). J. Amer. Soc. Hort. Sci. 126:661-667.

Zhang, X.S. and S.D. O'Neill. 1993. Ovary and gametophyte development are coordinately regulated by auxin and ethylene following pollination. Plant Cell 5:403-418. 